\title{
IMÁGENES Y AUTO-IMÁGENES EN EL MOVIMIENTO ÉTNICO BOLIVIANO*
}

\section{Xavier Albó \\ Centro de Investigación y Promoción del Campesinado - Bolivia}

Resumen: En este trabajo contrastaré las imágenes que los grupos indígenas de Bolivia han recibido y, sobre todo, presentan de si mismos, por caminos que no siempre coinciden con los que les proponen los sectores dominantes, ni siquiera los que se consideran sus aliados, ni con los que han acuñado algunos teorizadores. El texto privilegia la anécdota, el testimonio y el dato empírico, dentro de algo que podríamos llamar las categorías de etno-etnicidad en proceso de etnogénesis.

Resumo: Neste trabalho, contrastarei as imagens que os grupos indígenas da Bolívia tenham recebido e, sobretudo, apresentam de si mesmos, por caminhos que nem sempre coincidem com aqueles que lhes propõem os setores dominantes, nem mesmo os que se consideram seus aliados, nem com os que têm cunhado alguns teóricos. O texto privilegia a anedota, o relato e o dado empírico, dentro de algo que poderíamos chamar de categorias de etno-etnicidade no processo de etnogênese.

\section{Nombres propios y nombres dados'}

La actual conformación geográfica y socio-cultural de las identidades de los pueblos indígenas es en gran medida hechura colonial. Por ejemplo, se es quechua, aymara o guaraní no tanto por compartir una misma historia

\footnotetext{
* Adaptación de un trabajo presentado en el coloquio "Nuevas imágenes nacionales del indio" de CIESASCEMCA (México, septiembre de 1995) con algunos otros elementos complementarios.

1 Como simple relator del proceso, usaré términos como “indio”, “indígena”, “étnico” y, para ciertos momentos, también “campesino”, de manera pragmática sin tomar posición sobre la vigencia actual de cada término en cada contexto y para cada grupo, pues las cargas semánticas adicionales pueden variar mucho de un caso a otro.
} 
ancestral sino por hablar ahora la lengua correspondiente, aunque se trate históricamente de urus, chané u otros pueblos.

Existen además otros muchos términos con carga étnica para diferencias a unos pueblos de otros, muy particularmente a indígenas vs. blancos de origen español o mestizo. Como ocurre en tantos otros pueblos indígenas, muchas de las autodenominaciones significan "persona" o algo semejante, mientras que los términos dados a los otros están llenos de cargas negativas, comparables a las que tienen el nombre de indio o indígena en boca de los blancos. Dentro de la amplia gama existente, sólo presentaré algunos ejemplos del ámbito boliviano.

En el área andina:

- runa ('persona' en quechua) y jaqí (id. en aymara) vs. q'ara ('pelado', 'desnudo', 'incivilizado', siempre peyorativo). En labios de quechuas y aymaras.

- indio, indígena. Nombres dados por los que no lo son, casi siempre con connotación peyorativa, salvo en ciertos contextos académicos y políticos.

- cholo. Id. a los mestizos (biológicos o sólo culturales) que mantienen ciertos trazos culturales indígenas. Sólo el diminutivo femenino cholita puede tener un toque cariñoso.

- mujer de pollera (= chola o india) vs. mujer de vestido.

En el área oriental:

- colla (andino; quechua o aymara) vs. camba (oriental) como nombres peyorativos dado por cada grupo a otro.

- camba, nombre peyorativo dado por los blancos no-indígenas de las tierra bajas a los indígenas orientales de cualquier grupo.

- karai karayana... Algunos de los nombres peyorativos dados a los blancos por diversos grupos étnicos orientales.

- mbia ('hombre’ en guaraní) vs. karai ('blanco'; originariamente 'divinidad', pero ahora peyorativo). En los labios guaraní.

- ava ('persona' en guaraní) vs. tapii ('choza', 'esclavo') al referirse a los guaraní-chané del Isoso. En labios ava.

- cristiano (blanco) vs. gentil (guaraní) o bárbaro (ayoreo). En labios de los blancos, sobre todo hacendados. 
Estos y otros términos de larga data mantienen plena vigencia en el habla familiar de los diversos grupos implicados y sirven para fijar las relaciones interétnicas en la vida cotidiana.

Como en otras partes, el nombre dado por otros no siempre coincide con el preferido por los interesados. Por ejemplo, la mayoría habla de los matacos (o algunos más sofisticados, de los noctenes), pero los interesados quieren ser reconocidos como weenhayek. Incluso un intento de recuperar el antiguo nombre de chiriguano -lleno de resonancias etnohistóricas ${ }^{2}$ - en vez del demasiado genérico 'guaraní', fracasó, entre otras causas, por la influencia de la escuela que repite la historia de que los inkas interpretaron ese nombre como chiri wanu 'estiercol frío'. Los guaraní del Isoso, por ejemplo, no aceptan ser llamados tapii (como hacen sus hermanos avaguaraní) y hoy ni siquiera reconocen su ancestro chané (como lo explican los etnohistoriadores). Prefieren autodenominarse simplemente guaraní o a lo más guaraní-isoseño.

Por sus connotaciones con frecuencia negativas, ha habido diversos intentos de superar las categorías populares. Por ejemplo, es típico en los programas de radio y TV hablar de "las mujeres del pueblo" cuando en un desfile aparece un grupo de "mujeres de pollera” o cholas, términos más comunes, pero menos aceptados. Pero la transformación más significativa y masiva ocurrió a nivel nacional a raíz de la revolución nacional de 1952. Para comprender mejor esta evolución, hagamos un rápido recuento histórico.

\section{De indios a campesinos}

El arreglo colonial, sobre todo en la región andina que estaba más integrada al sistema, había sido el de un régimen estamentado con una sociedad superpuesta sobre la otra: la "república” de españoles y la "república” de indios, con una obvia y humillante subordinación de la segunda a la primera, pero también con un cierto reconocimiento de la segunda, a través de un implícito contrato de respeto a sus territorios a cambio de tributo y mita. Este arreglo se deterioró tras las reformas borbónicas, a fines de la

2 Los estudiosos piensan que proviene de un término que significaría el guaraní que adoptó una mujer chané. 
Colonia, motivando los grandes levantamientos de Tomás Katari; TupaqAmaru y Tupaq Katari en 1780-81, y se desmoronó totalmente, ya en la época republicana, en la segunda mitad del Siglo XIX con el ataque frontal a las "ex-comunidades”, que instauró una relación aún más asimétricas con “ciudadanos”, en un bando, y una indiada desestructurada y no reconocida en el otro. El mejor indio era el peón de hacienda sin tierra propia, porque algo podía aprender de su patrón blanco. El darwinismo social daba a su vez una justificación ideológica pseudocientífica a esta superioridad blanca (Demelas, 1981).

Desde entonces la reivindicación fundamental de los interesados, muy particularmente en todo el movimiento cacical de los años 1920 y 30 -ahora reivindicado por los aymaras del Taller de Historia Oral Andina (THOA, 1984, etc.)- tuvo dos referentes principales: la defensa de sus títulos y el pleno acceso a la educación. Aparte de la motivación económica de la primera, en ambos frentes estaba implícito el tema de la ciudadanía.

La derrota del Chaco en 1935, que cuestionó radicalmente aquel ordenamiento sociopolítico, puso en primer plano esta última temática, que quedó finalmente plasmada en las propuestas del gobierno del MNR (Movimiento Nacionalista Revolucionario) después de la revolución que lo llevó al poder en 1952, como parte de su ideología "nacionalista” unificadora y de una política de integración, el MNR intentó borrar del lenguaje público toda referencia a lo étnico. El ideal de aquel nacionalismo era llegar a crear una nación mestiza y culturalmente uniforme en que todos fueran ya igualmente bolivianos, sin referencia a sus diversos orígenes étnicos.

Los indios empezaron a ser rebautizados oficialmente como campesinos. Sus ayllus o comunidades se transformaron en sindicatos campesinos, a igual que las ex-haciendas recuperadas por la Reforma Agraria de aquellos mismos años. Las anteriores oficinas de asuntos indígenas subieron de rango en el organigrama estatal y dieron paso al Ministerio de Asuntos Campesinos. Las pocas escuelas indígenas del pasado empezaron a proliferar bajo el nuevo nombre de escuelas rurales dependientes del citado Ministerio. Supieran o no leer y escribir, todos ellos (y ellas) tenían ahora derecho a votar y algunos de ellos llegaron a ocupar ciertos cargos dentro del gobierno... 
Todo ello era una expresión pionera de una corriente que fue imponiéndose en el Continente durante la llamada desarrollista de los años 60. Tanto desde la izquierda como desde la derecha toda referencia étnica era mal vista, como una forma larvada de racismo, que debía ser superada por una visión exclusivamente de clase, o simplemente como algo primitivo condenado a desaparecer con los rápidos procesos modernizadores.

Los propios pueblos indígenas parecían haber entrado de lleno en esa nueva lógica modernizadora. Desde su perspectiva el nuevo cambio de enfoque podría resumirse en la siguiente frase: “Tanto nos dicen que somos indios brutos que debe ser verdad. Olvidémonos de nuestros orígenes, imitémosles y por fin progresaremos.” La mitificación de la escuela solía ser parte de esta misma lógica: “Que nuestros hijos se castellanicen y adquieran una profesión, preferentemente en la ciudad para que se civilicen y no sufran como nosotros."

Pero romper estructurales mentales y culturales tan arraigadas no es tan sencillo; menos aún cuando vienen acompañadas de una centenaria estructura de colonialismo interno en las diferentes esferas de la sociedad. En el lenguaje popular siguieron vivas las antiguas referencias étnicas e incluso la nueva terminología oficial fue reinterpretada en esos términos. En 1970, al preguntar a un vecino ele un pequeño pueblo provincial cochabambino si él era “campesino", en seguida él respondió ofendido: "Yo no soy campesino! Soy un humilde agricultor!” El primer término no era ya interpretado como una categoría social y productiva sino como un nuevo sinónimo de indio.

De manera semejante, las estructuras estatales empezaron a tomar un esquema dualista. Pasado el momento inicial de euforia, en los años 60 la educación rural volvió a formar parte del Ministerio de Educación y el Ministerio de Asuntos Campesinos se fusionó con el de Agricultura con la sigla MACA (Ministerio de Asuntos Campesinos y Agricultura). Pero en ambos ministerios se mantuvieron como instancias separadas la educación rural (vs. la urbana) y la secretaría de asuntos campesinos (vs. la de agricultura), de modo que los antiguos y hoy camuflados indígenas seguían teniendo un tratamiento diferenciado del resto.

Para la mayoría de los interesados, el camino escogido seguía siendo la participación a partir de los canales abiertos por el propio gobierno. A saber, como campesinos a través del movimiento sindical campesino y, en algunos 
casos, a través de la universidad, a la que una minoría ya lograba acceso, o de la militancia en alguno de los partidos tradicionales. Según las diversas coyunturas y preferencias, unos se acercaban más a las tendencias de derecha (más viables durante las dictaduras militares) o a las de izquierda. Pero se movían dentro de los canales establecidos, dentro de los que apenas aparecía la dimensión étnica.

Pero en el fondo estos ex-indígenas seguían sintiéndose marginados y empezaron a quejarse públicamente de que se les trataba como a "ciudadanos de segunda" o incluso como a "extranjeros en su propia tierra”. Por una parte el proyecto uniformador del nacionalista MNR originaba estas quejas al haberse quedado a medio camino. Pero, por otra, era esa integración siquiera parcial lograda por el MNR, la que había abierto los ojos de esos nuevos ciudadanos. Por eso podían ya hacer sus propios reclamos. Estaba empezando una nueva fase.

\section{De campesinos a kataristas}

Las primeras expresiones de recuperación de la identidad étnica surgieron, al nivel de bases, entre campesinos establecidos en la ciudad de La Paz. Una nueva generación de aymaras que estudiaban allí, comienzan a organizarse, fundando el Centro Cultural 15 de Noviembre. Bajo la mirada del pionero indianista Fausto Rainaga, descubren la figura histórica de Tupaq Katari -ejecutado en 1781- y empiezan a percibir sus problemas desde otra óptica. Con los años ellos serán los fundadores del Katarismo y de su rama más indianista, en la que tuvo un papel importante Ramiro Reynaga, hijo del propio Fausto (Wankar, 1971; cf. Pacheco, 1992).

Esta reemergencia era fruto tanto de los cambios introducidos por el MNR en el agro desde 1953 como de su fracaso fundamental para integrar al "campesino" en toda la vida nacional. Cambios como la participación política a través del voto, el sindicato y el partido, la masificación de la escuela y las oleadas migratorias a la ciudad como resultado no buscado de la Reforma, habían ampliado notablemente el horizonte y las expectativas de quechuas y aymaras. Pero la gran promesa gubernamental -conducir, por ese media, al indígena/campesino al progreso- no se cumplía y entonces se recuperó la memoria étnica perdida. Como decía un katarista, "Nos dijeron 
que dejando de ser indios progresaríamos. Lo probamos y no dio resultado. Ahora lo exigiremos como indios."

En aquel primer momento los kataristas seguían considerando sin cuestionamientos al llamado sindicato campesino como su instrumento privilegiado de lucha. En realidad, una vez recuperadas las haciendas, sindicato venía a ser el nuevo nombre de la organización comunal de siempre, aunque expandida ahora hasta un nivel nacional. ${ }^{3}$ Pero a nivel ideológico toma, entonces, relieve la lucha anticolonial de los indios del país con una lectura histórica más profunda. Más allá de la recuperación simbólica de las figuras de Tupaq Katari y su esposa Bartolina Sisa, perciben que el problema central es la persistencia de una situación colonial, por la que una minoría sociocultural sigue oprimiendo a una sociedad preexistente.

El Katarismo había saltado a la palestra pública a fines de los años 60, primero a través de los participativos programas radiales y otras actividades del llamado Centro Cultural Tupaq Katari, y en seguida, a través de la rápida toma de la organización sindical nacional entre 1970 y 1971. El mismo año, con el golpe militar de Banzer, debió pasar a la clandestinidad, pero desde ella siguió actuando. Fue un hito histórico el Manifiesto de Tiwanaku, suscrito en 1973 por cuatro organizaciones al pie de las grandiosas ruinas preincaicas, difundido clandestinamente en castellano, quechua y aymara, y utilizado como texto para la formación de cuadros en plena dictadura de Banzer; en él se subraya que la opresión no es sólo económica y política sino que tiene fundamentalmente raíces culturales e ideológicas. Cuando en 1979 cayó el régimen de Banzer, los kataristas retomaron la Confederación Nacional Campesina a la que añadieron primero el aditamento “Tupaq Katari” y transformaron después en CSUTCB (Confederación Sindical Única de Trabajadores Campesinos de Bolivia) por acuerdo con otras fuerzas políticas.

\footnotetext{
3 Por ejemplo, cada "sindicato" corresponde a una comunidad y la afiliación no es libre sino automática, por el mero hecho de tener tierras en la comunidad. En mayor o menor grado y con muchas variantes según el lugar, en lo más básico las autoridades son nombradas según los mecanismos tradicionales y cumplen las obligaciones de siempre, como gobierno comunal. Lo reivindicativo emerge sobre todo en los niveles superiores de la organización (Ticona; Rojas; Albó, 1995).
} 
En cuanto a la terminología que acompaño a este proceso, lo más evidente fue el redescubrimiento de la propia identidad aymara. El entonces estudiante de filosofía Juan Condori Uruchi lo expresó así en un artículo de prensa:

Actualmente nos llaman 'campesinos'; y los que somos aymaras obreros, mineras, profesionales e intelectuales, hemos sido despojados de nuestra personalidad del pueblo AYMARA. ${ }^{4}$

Años después, la Tesis Política del II Congreso de la CSUTCB (1983), que seguía hegemonizada por los kataristas empieza con un solemne preámbulo, significativamente titulado “Quiénes somos?”, que refleja este mismo descubrimiento:

Los campesinos aymaras, quechuas, cambas, chapacos, chiquitanos, canichanas, itonamas, cayubabas, ayoreodes, tupiwaraníes [sic] y otros, somos los legítimos dueños de esta tierra. Somos la semilla de donde ha nacido Bolivia, pero aún hasta ahora hoy nos tratan como a desterrados en nuestra propia tierra.

El largo listado de pueblos indígenas no es casual. Refleja la dificultad de encontrar un término genérico para expresar lo común a todos ellos, en la anterior cita se llama a todos ellos “campesinos” debido a que el contexto era un congreso efectivamente campesino. Pero en otras partes del documento del CSUTCB (1983) ya se habla de "los diversos pueblos que habitamos estas tierra” y concluye con un llamado a

la construcción de una sociedad plurinacional que, manteniendo la unidad de un Estado, combine y desarrolle la diversidad de las naciones aymaras, quechua, tupí-guaraní, ayoreode y todas las que la integran (el subrayado es nuestro).

4 Semana de Última Hora, 4-VI-1976. 
"Pueblos” y “naciones” son términos cuyo uso irá creciendo en los años siguientes pera entonces sonaban a muy novedosos, sobre todo el segundo y la audaz propuesta de un estado plurinacional.

Pero la alternativa que por entonces se estaba manejando era la autodenominarse indios, aunque el término seguía siendo muy controvertido. Dentro del Katarismo ya en 1978, con ocasión de las primeras elecciones constitucionales, surgió incluso una división entre dos sectores: los indianistas y los kataristas, en sentido estricto, cada uno con su propio partido político: el MITKA (Movimiento Indio Tupaj Katari) y el MRTK (Movimiento Revolucionario Tupaj Katari), que después se dividirán en varios más.

Los indianistas atribuían sus problemas casi exclusivamente a la situación creada desde los principios de la Colonia. Usaban una retórica dura contra los blancos o blancoides y, al menos en el discurso, rechazaban toda alianza con ellos. Cuando se les argüía que el término indio sólo reflejaba un error de los primeros españoles que creían haber llegado a la India, respondían: "Como indios nos explotaron, como indios nos liberaremos".

Los kataristas estaban más relacionados con otros grupos de izquierda. Sentían también con fuerza la discriminación de origen colonial, pero la combinaban más con la de clase y más fácilmente aceptaban que, para liberarse, debían unir fuerzas con otros grupos como los obreros, los mineros, los "sectores progresistas" de la iglesia o algunos partidos de izquierda, aunque tenían también mucho cuidado de no identificarse demasiado con ellos. Una típica expresión de aquellos años era que debían mirar la realidad con dos ojos y avanzar con dos pies: el de aymaras oprimidos, junto con los demás pueblos oprimidos; y el de explotados, junto con toda la clase explotada; es decir, el eje colonia (o nacionalista) y el eje clasista.

Es de notar el tenor que en aquellos años tomaba el debate sobre el racismo. Tanto en la derecha como en la izquierda se veía con recelo todo este movimiento y muchos lo tildaban de racista. Los acusados se defendían diciendo que ellos se limitaban a reaccionar frente al racismo blanco. Este ataque iba dirigido con más fuerza contra la corriente indianista, hasta el punto que en aquella época varias publicaciones de la CSUTCB katarista debieron explicar en sus créditos (tal vez para aplacar a quienes se las financiaban) que ellos estaban en contra de todo racismo. 
A un nivel más vivencial, resurgía a veces la memoria histórica del duro cerco que Tupaq Katari mantuvo sobre la ciudad de La Paz durante casi seis meses en 1781, creando en los no indígenas un trauma colectivo que revive en momentos de amenaza. Así ocurrió, por ejemplo, en 1979 cuando el CSUTCB decretó un bloqueo de caminos que paralizó buena parte del país durante varios días. Aconteció entonces un publicitado episodio con numerosos peregrinos y contrabandistas que, atrapados en el santuario fronterizo de Copacabana, habían logrado captar la atención de una "cadena radial de emergencia” que en aymara y quechua llamaban a los bloqueadores a la cordura; en dicha cadena el miedo étnico de los citadinos rezumaba en sus reiterados llamados a los hermanos campesinos. La Cruz Roja intervino a favor de los bloqueados en Copacabana ante el dirigente aymara Jenaro Flores: "Ya llevan cuatro días esperando!" La respuesta fue contundente: “Nosotros llevamos más; más de cuatrocientos años!”.

Con los años se ha ido dando un mayor acercamiento entre la doble corriente katarista e indianista. Ha seguido habiendo quienes se han acercado más a otros partidos, primero de izquierda y posteriormente también de derecha, quienes han formado nuevos partidos (como el Eje Pachakuti ${ }^{5}$ de Félix Cárdenas) y quienes han tomado posturas más fundamentalistas. No han faltado incluso algunos intentos de lucha armada, aunque en ellos el uso de lemas kataristas sólo en casos contados ha implicado la presencia de genuinos aymaras o quechuas. ${ }^{6}$ Pero el elemento común a lo largo del espectro de opciones prácticas es que todos ellos reconocen ahora que es el colonialismo interno el factor fundamental que atraviesa casi todas las relaciones y condiciona la aceptación de los campesinos e indígenas como ciudadanos de primera clase.

5 Término quechua/aymara de raíces precoloniales que significa 'cambio de era'. La conquista colonial fue inicialmente vista como un pacha kuti: "el mundo al revés”, decía Guaman Poma. Los misioneros coloniales lo usaron para referirse al Juicio Final y recientemente se ha utilizado con frecuencia en los medios indianistas y kataristas para referirse a un cambio radical revolucionaria.

6 El más célebre de ellos es el aymara Felipe Quispe. Junto con otra gente de origen más urbano, fue líder de los Ayllus Rojos, posteriormente reorganizados como el Ejército Guerrillero Zárate Wilka. Cuando fue detenido, una periodista le preguntó si no le dolía que en uno de los atentados hubiera muerto accidentalmente alguna gente. Lamentó el incidente y añadió: "Y a Ud. no le duele que mi hija Lenga que ser su sirvienta?”. 


\section{Los procesos aduales}

Tras los obligados paréntesis impuestos por diversas dictaduras militares, el movimiento katarista llegó a su clímax a principias de los años 80, cuando se restableció la democracia. Pero ésta coincidió con una grave. crisis económica que condujo a la pérdida de credibilidad política tanto del gobierno como de las organizaciones populares que lo cuestionaban. Junto con éstas, el movimiento katarista también se dividió y perdió impulso.

Ocurrió entonces lo paradójico. Al tiempo que, por diversos conflictos internos, se diluía el movimiento organizado, sus ideas centrales, antes resistidas por la clase política, calaban en el ambiente y pasaban a formar parte del discurso nacional, mucho más allá del mundo aymara. Incluso las organizaciones de productores de la "sagrada" hoja de coca apelan al discurso étnico. Más aún, en los últimos años, coincidiendo con la nueva coyuntura mundial, la temática étnica ha llegado a penetrar también en la retórica de casi todos los partidos políticos. Uno de ellos -CONDEPA (Conciencia de la Patria) fundado por un ex-folklorista y pionero de la radio y TV en aymaratuvo una primicia al ofrecer y lograr una banca en la Cámara de Diputados a una cholita de pollera.

Pero la máxima expresión de este ascenso de lo étnico en la clase política fue que el MNR propuso (y también logró) la vicepresidencia del país para un indígena. En efecto, en las elecciones de 1993, triunfó masivamente una forma política que tenía como presidente al máximo exponente de las reformas neoliberales y jefe del MNR (que en los años 50 había pretendido borrar el tema étnico) y, como vicepresidente, a un aymara que desde los años 70 había sido uno de los principales líderes intelectuales del todo el movimiento katarista. Es un hito de gran fuerza simbólica, pero no exento de ambigüedades tanto por la diferencia de intereses entre los dos aliados como por las reacciones contradictorias que este hecho suscitó en los sectores indígenas y populares (Albó, 1993, en prensa).

Para comprender lo que ha implicado todo este proceso, en términos de una nueva toma de identidad étnica, he escogido el análisis de dos debates: (a) entre campesinos-indígenas y obreros, y (b) entre diversos tipos indígenas. 


\section{El debate con los obreros}

La historia de las relaciones entre los campesinos-indígenas, por un lado, y de los obreros, por el otro, en torno a la COB, ${ }^{7}$ nos ayudará a entender vivencialmente el cruce del prejuicio étnico y una nueva propuesta plurinacional con la que a veces se llamó una "alianza natural” entre obreros y campesinos.

Cuando se creó la COB, a principios del gobierno del MNR en 1952, la Confederación Nacional de los sindicatos campesinos eran parte de ella. Pero a medida que aumentaron los conflictos de aquella con el gobierno, los campesinos se alinearon más bien con el gobierno que les "había dado tierras”. Años después, un sector de dirigentes campesinos que se había separado del oficialismo fue acogido de nuevo en la COB como Bloque Campesino Independiente. Pero su representatividad era poca y sú dependencia del partido PCML (de tendencia china) era total.

En 1978 los kataristas retomaron la Confederación campesina e hicieron pasos de acercamiento a la COB, pero chocaron con la oposición de aquel partido y con el discurso dominante de la izquierda de entonces, que consideraba a los campesinos como el furgón de cola de los movimientos revolucionarios porque, al ser ya dueños de sus parcelas, eran técnicamente “pequeños burgueses”. Detrás de esa jerga conceptual se camuflaba el prejuicio étnico de siempre: los obreros y mineros, aunque proletarios, ya estaban civilizados, mientras que esos campesinos, en el fondo, seguían siendo indios. El dirigente campesino cochabambino Enrique Encinas, él mismo ex-dirigente campesino minero me resumió el problema con la frase: "Es que en el fondo nos desprecian; los conozco muy bien.”

Comenta Jenaro Flores, el primer Secretario Ejecutivo de la CSUTCB ${ }^{8}$

Nosotros asistimos a los ampliados de la Central Obrera Boliviana, simplemente como oyentes, nunca nos han dado importancia. Los trotskystas... nos

\footnotetext{
Central Obrera Boliviana, instancia única que desde 1952 aglutina a todos los trabajadores del país y que durante muchos momentos políticos ha jugado un rol fundamental, a veces superior incluso al de los partido.

8 Esta cita y las siguientes provienen de entrevista reproducida en el capítulo 4 de Ticona, Rojas y Albó (1995) del que hemos retomado también buena parte de esta historia.
} 
decían: “A los kataristas, a los indianistas hay que controlarlos... A estos indios hay que controlarlos”. Así, no? Pero nosotros no queríamos entrar ahí para ser controlados.

Al fin se llegó a un acuerdo. La COB convocó un Congreso de Unidad en junio de 1979, en que se logró la fusión de las principales organizaciones y nació la CSUTCB (Confederación Sindical Única de Trabajadores Campesinos de Bolivia), afiliada ya a la COB, pese a la resistencia de algunos partidos entonces con mayor influencia dentro de ella. Pero más allá de lo político, seguía aflorando siempre lo étnico. Flores, nos sigue comentando, había observado que los campesinos “independientes” eran muy dependientes de los obreros de su mismo partido:

Les mandaban a comprar refrescos y obedecían de callado. Yo me dije, entraremos en la COB, pero no para írselo a comprar refrescos. Cuando por fin entramos en la COB un día el dirigente NN. me dijo: “Compañero Flores, puedes ir a comprar cigarrillos?” Yo le contesté: “Cómo no. Si tú me lustras los zapatos, yo iré a comprar tus cigarrillos.” Comprendieron que yo no era lo mismo.

Como no fue fácil el reconocimiento de la COB a la CSUTCB, tampoco lo fue el ocupar más carteras, y más significativas, dentro de la estructura sindical-obrera. La primera que lograron era, como recuerda Flores, un cargo meramente simbólico, que expresaba el sutil rechazo a los campesinos del país:

En ese entonces yo tenía un cargo de hazme reír: secretario de milicias armadas. Nosotros nos reíamos porque la COB tenga ese cargo... No tenía milicias armadas, ni un revolver, ni una q'urava [honda].

Se consiguió alguna cartera mejor, pero durante años el campesinado, pese a ser la amplia mayoría demográfica dentro del sector trabajador, seguía tratado corno minoría en la COB. La plena hegemonía proletaria y minera se consideraba cuestión de principio ideológico, establecido incluso en los estatutos de la Central Obrera. Hubo que pasar por la profunda crisis laboral e ideológica de la clase obrera, tras el cierre de las minas en Bolivia y la caída del “comunismo” en Europa, para poder plantear una representación más equitativa dentro de la directiva de la COB. Fue un debate duro 
y de varios años, en el que -de nuevo- se mezclaron intereses políticos y prejuicios étnicos.

Recién en 1989, en el VIII Congreso de la COB realizado en Oruro, la organización campesino reclamó mayor participación en el Comité Ejecutivo Nacional. Argüía que el cambio social y económico que vivía el país exigía modificar la estructura de la COB para fortalecerla. La contrapropuesta obrerista decía que no debía modificarse nada, pues los cambios eran solamente fenómenos coyunturales y que dentro de un año el proletariado volvería a recuperar su fuerza y rol protagónico. Llegada la votación, ganó el planteamiento campesino con el apoyo de los debilitados mineros, pero el importante sector fabril rechazó el resultado y abandonó el Congreso. Los campesinos decidieron tener paciencia para evitar la división de la COB. Entretanto, en señal de protesta, dejaban vacantes sus carteras habituales. Al comunicar esa decisión, su dirigente Juan de la Cruz Villca dijo a los otros congresales:

No retiramos nuestro pedido. Simplemente lo postergamos hasta el próximo Congreso. Si hemos esperado 500 años, no es mucho esperar dos o tres años más. Reflexionen en este tiempo, compañeros, y nos volveremos a encontrar.

En los hechos, la espera se prolongó por dos congresos más, hasta que por fin, en el IX Congreso de 1992, los campesinos lograron una mayor cuota y la segunda cartera en importancia. Las siguientes citas de las intervenciones de la CSUTCB sacadas del excelente resumen de Arias (1991) indican que, tras el juego político por cuotas de poder, salían a relucir temas más de fondo sobre las raíces étnicas del país y la reformulación de los conceptos políticos hasta entonces vigentes:

La teoría [de la vanguardia revolucionaria obrera] viene de afuera, de Europa. Por qué no teorizamos aquí? Estas teorías que vienen nos hacen emborrachar. Entonces estamos repitiendo como borrachos lo que hemos aprendido. Parece que no tenemos capacidad de teorizar nuestra propia realidad. (Delegado anónimo).

Ahora que se ha roto el espejo europeo donde [ustedes, obreros] se peinaban, se miraban y funcionaban, ese espejo de ha roto, no tienen otro camino, si quieren seguir peinándose y funcionando, que mirarse en nosotros. Mírense 
en nosotros. Nosotros somos ustedes, ustedes son nosotros y, así juntos vamos a avanzar! Hemos vivido 500 años de sangre, pero también 500 años de esperanza, que la sangre no tape la esperanza. (Félix Cárdenas).

Ahora lo que hay que atacar es el concepto de alianza, que es un fracaso. No podemos estar sólo aliados. Cómo me voy a aliar con NN [un dirigente minero] que tiene raíz aymara? Hemos estado como en un especie de concubinato, desconfianza y desconfianza, para que alguien se aproveche. Entonces ahora queremos matrimonio. Convivir, eso qué es? La unidad real entre nación originaria y la clase es nuestra teoría. (Juan de la Cruz Villca).

\section{Los debates entre grupos indigenas}

Hasta aquí nuestros testimonios se han referido sobre todo a la región andina y occidental del país, que fue la más integrada en la sociedad global desde la temprana época colonial. La problemática paralela de los pueblos indígenas del Oriente (parte baja y tropical del país), más diversificados y minoritarios, ha sido un desarrollo más reciente, con sus propias características y aportes.

Los primeros pasos hacia la formación allí de un movimiento étnico ocurrieron a fines de los años 70 con el apoyo de una ONG que conocía la experiencia de AIDESEP en el Perú. Significativamente, siguiendo los vientos dominantes del país, esa institución se llamó Apoyo al Campesinado del Oriente Boliviano (APCOB). Gracias APCOB en 1982 surgió una organización de base conocida ahora como Confederación de Indígenas del Oriente Boliviano (CIDOB) y que, con el apoyo de otras organizaciones surgidas más localmente, representa hoy a los principales grupos indígenas orientales.

La principal toma de conciencia nacional sobre la problemática de estos indígenas orientales ocurrió en 1990 como resultado de una masiva marcha a pie de 700 kilómetros durante más de un mes desde los Llanos tropicales hasta la cumbre de la Cordillera andina y La Paz. La iniciaron cuatro grupos de Moxos sobre todo en protesta por la depredación causada por los madereros, tuvo gran cobertura de algunos influyentes medios de comunicación y fue apoyada por 12 grupos indígenas del país, la CSUTCB y la COB. Los aymaras, presididos por sus dirigentes, los recibieron cálidamente en la 
cumbre nevada de la Cordillera en medio del sonido de patutus (cuernos) y el hondear de whiphalas (banderas aymaras) y sellaron con ellos un pacto de sangre mediante el sacrificio ritual de una llama (Contreras, 1991).

El lema de la movilización fue "Marcha por el Territorio y la Dignidad”. La palabra dignidad reflejaba el nuevo deseo de ser considerados ciudadanos de primera. La palabra territorio enfatizaba un aspecto más relegado en el mundo andino. La Reforma Agraria había adoptado el lema mexicano "la tierra es de quien la trabaja” y había fomentado la propiedad parcelaria de los pequeños productores, con alta aceptación de los interesados. En cambio entre los grupos indígenas del Oriente, en medio de su menos conciencia de la legislación boliviana y una vida menos ligada a una parcela, se mantuvo más viva cierta vivencia de su territorio étnico; en el pasado no fueron raros los conflictos inter-étnicos para defenderlo y ya en los años 20 se sabe de algunos mburuvicha o jefes guaraní que emprendieron largas caminatas hasta La Paz para ratificar ante el Presidente sus derechos territoriales. Ahora, ésta era la demanda central de la marcha y, de hecho, como resultado de esta movilización, se lograron hasta 1993 un total de nueve decretos supremos que concedían 2,9 millones de hectáreas a un total de 11 pueblos indígenas orientales. Lamentablemente ni el gobierno de entonces cumplió su promesa de ratificar esta decisión en una Ley Indígena ni el siguiente ha avanzado un centímetro en esta línea, por considerarlo un tema vidrioso tanto en lo jurídico como para los intereses económicos de sus aliados.

Desde entonces el tema de los territorios indígenas ha entrado de lleno en el debate público y el concepto ha sido también recuperado por los pueblos andinos. En plena marcha, los aymaras recogieron el reto territorial que planteaban sus hermanos de las tierras bajas y les entregaron una gran llave simbólica de la ciudad de La Paz, en el corazón de su propio territorio.

La mencionada Ley Indígena era otra promesa arrancada al gobierno durante la marcha. Nunca llegó a cumplirse, pero los numerosos talleres y reuniones que tuvieron las principales organizaciones (incluida la CSUTCB) durante más de un año, fueron una excelente oportunidad para analizar, entre otros muchos, el tema de la oportunidad indígena y los términos más adecuados para expresarla.

En efecto, desde su mismo título, la propuesta de Ley Indígena exigía preguntarse quiénes son indígenas. El término indígena es muy común en 
las organizaciones de base de otros países y es también el más aceptado en esferas oficiales. Se usa, por ejemplo, en el Convenio 169 de la OIT y en Decenio Mundial de las Poblaciones Indígenas, iniciado por Naciones Unidas en 1994. Sin embargo, en la Bolivia andina, era muy mal visto por los propios interesados desde los años 50. En el resurgir de su conciencia étnica las poblaciones andinas sólo habían rescatado los nombres de sus respectivos pueblos, ahora llamados también nacionalidades, naciones y -no sin controversias- indios. En cambio los pueblos orientales, que no habían tenido la misma vivencia de 1952, veían normal autodenominarse indígenas, para diferenciarse de manera genérica de los karaí o karayana (blancos); el mismo gobierno y, durante la marcha, los medios de comunicación apoyaron este uso, que estaba muy en consonancia con la corriente internacional.

Surgieron así dos problemas algo relacionados: la reducción de indíge$n a$ a sólo los grupos étnicos minoritarios del Oriente por parte del Gobierno (y, en cierta medida, de los protagonistas de la marcha) y, a la vez, la reticencia de los andinos a identificarse con esa misma denominación. Salvo en los grupos orientales, tanto en el uso por parte de los no-indígenas como en la reticencia de los andinos seguía implícita, de alguna manera; la impresión de que ese término implicaba gente "silvícola”, “poco civilizada”. Cuando, por ejemplo, al fin de su larga marcha los "indígenas” orientales llegaron a La Paz había curiosidad entre los sectores populares paceños -muchos de ellos de origen aymara- para saber cómo vestían, qué cara tenían, etc.

Políticamente los andinos no deseaban reducir la Ley Indígena a sólo las tierras bajas. Pero psicológicamente se resistían a adoptar ese término, aunque tampoco aceptaban ya ser reducidos a campesinos. El tema fue motivo de fuertes debates tanto dentro de la CSUTCB como en otros eventos conjuntos con CIDOB y otras organizaciones indígenas del Oriente. Seguía pensándose que era mejor usar el nombre propio de cada grupo (quechua, serionó, etc.).

Con el tiempo el término indígena es ahora más aceptado, entre otros motivos por lo mucho que se ha publicado, dentro y fuera del país, que el, nuevo vicepresidente, el aymara Victor Hugo Cárdenas, es el primer indígena que ha alcanzado tal rango y por la mayor participación en eventos e instancias internacionales, como la gestación en Bolivia de la Década de los Pueblos Indígenas (con la notoria presencia del citado vicepresidente y 
de la indígena y Premio Nóbel Rigoberta Menchú), o el establecimiento en Bolivia de la sede del Fondo de Desarrollo Indígena.

Sin embargo, entre los interesados andinos el debate llevó más bien a acuñar un nuevo término que les satisface más: pueblos originarios o incluso naciones originarias. Para ellos este es el único término que no les ha sido dado por otros sino que ha sido pensado por ellos mismos y que, por lo mismo no tiene las cargas peyorativas de los otros. ${ }^{9}$

Es interesante constatar cómo, por caminos totalmente independientes, llegaron a una fórmula casi idéntica a la adoptada por los pueblos indígenas de Norte América que gustan llamarse first nations. Por otra parte, resulta también significativo ver que esa denominación -ahora ya aceptada oficialmente- no gustó a algunos grupos no indígenas. El periódico paceño Última Hora, por ejemplo, pronto publicó un editorial titulado: "Pueblos originarios, pero desde cuándo?”- Argüía que tan advenedizos eran los indígenas como los blancos; el hecho de que hubieran llegado sólo unos años o siglos antes no les daba derecho a llamarse "originarios". Reacciones similares han tenido incluso algunos insignes políticos y politólogos más sensibles a la problemática étnica, tal vez por sentirse en alguna forma relegados a ciudadanos de categoría inferior al no ser tan originarios. Tales reacciones resultan dignas de reflexión. Por primera vez son los de abajo los que hacen sentir a quienes siempre se consideraron arriba la posibilidad de que los primeros tengan algún título más honorable. En el fondo, con el término originario (aunque hubieran llegado sólo poco antes) rechazan el persistente esquema colonial y subrayan que ni la conquista ni la fuerza pueden ser éticamente fuente de derecho, un principio al que suelen apelar los estados en sus reclamos territoriales. Pese a significar etimológicamente lo mismo, qué distintas resultan las resonancias de indígena, aborigen u originario!

\footnotetext{
9 Es de notar que a nivel de dirigentes y bases casi nadie ha reivindicado el término etnia. Sólo hemos escuchado a un dirigente del grupo minoritario uru-murato usando espontáneamente el término cuando viajó a Pátscuaro, México, y allí descubrió a los purépecha, exclamó con alegría: “Aquí también hay etnias como nosotros!” (Moricio, 1992). Pero la mayoría lo ven como "cosas de antropólogos” y en muchos casos relegan a ese término los estigmas que antes tenían otras palabras hoy reivindicadas. Al rechazarlo un alto dirigente de la marcha indígena comentaba: “Acaso comemos hierba?” Pese a ello la nueva instancia gubernamental dedicada al tema ha sido llamada Subsecretaria de Asuntos Étnicos.
} 
Para comprender mejor la fuerza ideológica de las palabras, no nos resistimos a copiar algunos fragmentos de un texto del dirigente aymara Juan de la Cruz Villca, ahora el número dos dentro de la COB, elaborado al calor del debate a que hacíamos referencia más arriba. El título ya es significativo: "No podemos rezar lo que no es nuestro":

Hay diferentes opiniones y razonamientos. Como hay personas que "somos hermanos" dicen; que hay que dignificar esos nombres [de 'indio', 'indígena'] para levantarse con el mismo nombre contra la explotación; otros dicen que el nombre no les interesa un "comino". Pero otros decimos que sí nos interesa mucho el nombre porque no podemos seguir aceptando bautismos que ha significado la peor desgracia de humillación... Es cierto que no podemos tapar la boca de los que nos dicen o bautizan. Ellos seguirán diciéndonos, incluso publicándonos en la historia. Sin embargo nosotros mismo no podemos decirnos semejante humillación, porque eso significaría aceptar el bautismo de "indio-indígena” que ha servido para tratamos peor que un perro. (Una cosa es que ellos, los racistas descendientes de monarcas, nos digan perro, pero nosotros mismo no podemos llamarnos perro.). Por eso debemos levantar en alto nuestra identidad personal como pueblo, porque tenemos clavado en el profundo de nuestro corazón y conciencia de que somos aymaras, quechuas, guaraníes y otras nacionalidades y que nos enorgullece...

También hay otro razonamiento, cuando decimos Q'ara, Qharayana a los extraños, les estamos diciendo lo peor... Pero ellos no dicen que con el mismo nombre q'ara o qharayana vamos a seguir matando, saqueando los recursos naturales, etc. sino dicen "somos buenos bolivianos que estamos trabajando por un desarrollo, democracia, libertad de expresión...

Por eso la comisión redactora de la Ley de mayorías nacionales como el parlamento de las minorías y todo el pueblo tiene la responsabilidad de no seguir equivocaciones históricas... La Ley debería llamarse una ley de pueblos originarios de Bolivia que consoliden la unidad de todas la nacionalidades. (Villca, 1991).

Otra importante ocasión para profundizar identidades fue el año 1992, que llevó a repensar todo el lema de los 500 años en sus múltiples dimensiones: descubrimiento o encubrimiento, celebración o luto, invasión, colonización española, evangelización, giro en la historia, mestizaje, resistencia y vigencia actual de los pueblos originarios, etc. Ya hemos hecho reiteradas 
alusiones al tema en los testimonios citados, en todo la SCUTCB, el CIDOB y las otras organizaciones indígenas jugaron un rol mucho más protagónico que cualquier otro grupo social.

Una de las metas entonces más acariciadas fue la de crear "un instrumento político": la Asamblea de Nacionalidades, propuesta desde el I Congreso Extraordinario realizado en Potosí en 1988, debatida en varios encuentros y comités conjuntos de la CSUTCB y CIDOB y en otras varias instancias. La idea central era la constitución formal de las comunidades a través de sus autoridades originarias y del pueblo, y la creación de una instancia superior de todas ellas a nivel nacional. Se preveía incluso que esta última podía llegar a sustituir, o al menos coordinar con este nuevo enfoque de unidad en esa diversidad étnica, a las actuales organizaciones sindicales e indígenas, según el caso, como un paso importante hacia la constitución del acariciado estado plurinacional.

Mientras esta propuesta sólo era una idea, todos propugnaron la Asamblea y fue masiva su aceptación. Pero, a medida que se intentó darle cuerpo, surgieron los problemas prácticos y los juegos de intereses. No faltaron algunas voces que se preguntaban con recelo: Qué oculta la idea de la Asamblea de las Nacionalidades? Qué intereses políticos estarán detrás de ella? Estas contradicciones saltaron a la vista, con un gran éxito expresivo y un naufragio organizativo, en el momento mismo de su ejecución.

El 12 de octubre de 1992 vivió al mismo tiempo masivas movilizaciones, llenas de fuerza simbólicas y un doloroso fracaso en la instauración de la Asamblea. En las principales ciudades del país confluyeron grandes marchas de las organizaciones indígenas y campesinas, llegadas a veces después de muchos kilómetros de caminata militante. Las wiphalas ondeaban por doquier, más que nunca antes, provocando comentarios a veces de sorpresa, a veces de repudio: "no hay banderas bolivianas, solo hay wiphalas". ${ }^{10}$

${ }^{10}$ La wiphala, con su juego de siete colores es un campo de siete por siete cuadros, representa muy bien la imagen de una Bolivia diferente, pluriétnica. Aunque tiene raíces en la cultura andina, su emergencia como símbolo del pueblo aymara y después de la variedad de las “naciones originarias”, es un fenómeno de los últimos años. Han surgido incluso nuevas explicaciones sobre sus orígenes y significados (ver Chukiwanka, 1993). Hacia el fin de su mandato presidencial, Jaime Paz Zamora llegó a prometer que daría reconocimiento oficial de la whiphala como otro símbolo patrio. No llegó a cumplirlo, pero es común ahora encontrarlo incluso. 
Muy particularmente en La Paz, se habló mucho del cerco simbólico de la ciudad -a los dos siglos del de Tupaq Katari- y la escena fue la de una toma simbólica pero pacífica del centro del poder. La plaza Murillo, donde está el palacio presidencial, estuvo fuertemente acordonada por las fuerzas del orden, con soldado y policías de rostros muy andinos, con sus ponchos, pututus y wiphalas y representante de los demás grupos étnicos del país, recorrieron todo el cordón vitoreando vivas y mueras. La imagen de un sistema aún colonial que iba quedando cercado en la voluntad de estas multitudes, resultaba impresionante y será muy difícil olvidarla.

Concluidas las demostraciones, las diversas delegaciones se dieron cita en el Teatro al Aire Libre para la instauración formal de la nueva Asamblea de las Nacionalidades. Los diversos delegados acudieron, llenos de expectativas. Pero empezaron las dudas sobre quiénes debían ser los representantes, quiénes debían impulsar la organización definitiva. Cada grupo había temido ser instrumentalizado por el otro grupo y por los partidos que los apoyaban y no se llegó a una concertación creativa, al final un fuerte diluvio los dispersó a todos y selló el naufragio. A nivel organizativo, la Asamblea no sólo quedó aguada sino prácticamente liquidada.

La lección práctica es que es más fácil expresar un deseo que organizarse para llevarlo a cabo por encima de otros intereses contrapuestos. El evento muestra también la necesidad de encontrar mecanismos idóneos para articular las democracias étnicas, más locales y directas, con otros mecanismos complementarios de democracia indirecta y representativa a niveles superiores.

\section{Un proceso continental}

Sobra decir que todo este proceso de etnogénesis no es ni mucho menos algo exclusivo del escenario boliviano. También en otras latitudes, las primeras épocas republicanas siguieron proyectando los esquemas colonialistas, dándoles un nuevo toque de racismo más “moderno”; siguió después una tendencia a ignorar la dimensión étnica, sustituyéndola por categorías socio-económicas de apariencia más racional; y finalmente se viven ahora nuevos procesos de etnogénesis, que acaban por ser reconocidos por los demás sectores sociales. 
Más tarde o más temprano, con mayor o menor intensidad, cambios comparables a los mencionados han estado ocurriendo en otras muchas partes del continente, desde Chiapas, Oaxaca y Guerrero, en México, hasta el Parlamento de Brasília, donde la masiva presencias de grupos indígenas logró asegurar cambios favorables en la nueva Constitución. En la selva del Ecuador existe, desde 1961, la Federación Shuar, que pronto estimuló la creación de otras organizaciones en un proceso que culminó en 1982 con el nacimiento de la CONAIE (Coordinadora de Nacionalidades Indígenas del Ecuador. Son conocidos, por ejemplo, los dos masivos levantamientos indígenas que lideró en 1990 y 1994, forzando diversos cambios legales. En Colombia, a principios de los años 70, el flamante CRIC (Consejo Regional Indígena de Cauca) se desgajó de la omnipresente ANUC (Asociación Nacional de Usuarios Campesinos) y, a partir de los años 80, surgió la ONIC (Organización Nacional Indígena de Colombia), que ahora tiene incluso asegurado su derecho constitucional a tener representantes propios en el Parlamento. En Chile, tras el túnel pinochetista, reemergió con fuerza el movimiento tanto entre aymaras como entre mapuches habiendo logrado ya la dictación de una importante Ley Indígena...

Tanta sincronía nos hace pensar que hay elementos de tipo más estructural en toda esa emergencia étnica. Más allá de las variadas coyunturas y momentos locales, parecen vislumbrarse los siguientes factores comunes:

- La frustración post-desarrollista. Más tarde o más temprano, en todas partes las propuestas desarrollistas han fracasado y en muchos casos fueron incluso sustituidas por planes de desarrollo agropecuario más descaradamente favorables a las grandes empresas agroindustriales. Los indígenas tienden entonces a cuestionar el discurso "civilizatorio" y vuelven a enfatizar sus raíces.

- La expansión a las tierras bajas. Como parte de sus programas de desarrollo, muchos países se expandieron al área amazónica con caminos y empresas agroindustriales o madereras, motivando la reacción de los pueblos indígenas allí asentados, cuyo referente básico seguía siendo desde siempre su propia identidad étnica.

- La coyuntura ecologista. Ligado al factor anterior, está la emergencia de los movimientos ecologistas en el primer mundo. En su defensa de los recursos naturales, pasaron a primer plano las mayores reservas naturales, 
como es la Amazonía y, en ellas, descubrieron a los pueblos indígenas como a los que mejor habían aprendido a convivir con su medio ambiente sin degradarlo. La fuerza de ese movimiento en el Prímer Mundo ha hecho que incluso agencias como el Banco Mundial haya empezado a considerar el componente indígena en sus programas, a veces para despecho de nuestros gobiernos neocolonialistas.

- Una reacción al hiperclasismo de la izquierda. Inicialmente muchos movimientos indígenas se habían aliado con partidos de izquierda y sus ramas sindicales. Pero a la larga no se sentían allí suficientemente representados porque sus demandas más específicamente indígenas no hallaban eco en el discurso de clase. Con la caída de los regímenes “comunistas” de Europa Oriental, esta reacción ganó mayor fuerza, pues la izquierda perdió su referente fundamental. La avalancha neoliberal, que ya se había impuesto en muchos países desde años antes, acabó de sacar del escenario a los grupos organizados de izquierda, incluidos los obreros, entrados ahora en una fuerte crisis.

- Un nuevo enfoque de ciertas iglesias y otras instituciones no gubernamentales. Tras el Concilio Vaticano de los años 60, diversos sectores de la Iglesia Católica se acercaron más al mundo de los pobres y a los sectores rurales más olvidados, donde fomentaron una mayor participación de los grupos de base, incluyendo los pueblos indígenas. Pensemos, por ejemplo, en obispos como Samuel Ruiz, Leónidas Proaño o Pedro Casaldáliga. Pese al mayor fundamentalismo de muchos grupos protestantes, éstos tenían ya desde antes una fuerte presencia en sectores indígenas y su esquema menos jerárquico abría mayores posibilidades de las bases para llegar a niveles de liderazgo. Finalmente, llegó el booms de las ONGs que, en medio de su inmensa variedad, han sin duda facilitado la emergencia de respuestas alternativas desde las comunidades.

Hay también notables coincidencias, de uno a otro país, en el tipo de propuestas que las nuevas organizaciones indígenas platean a sus respectivos estados. Además de las demandas de servicios básicos para superar su actual condición de pobreza, prácticamente todos coinciden en otras formulaciones propositivas de contenido más claramente étnico: no ser considerados ciudadanos de segunda, tener ciertos márgenes de autonomía en su forma interna de organización y gobierno, una educación a partir de su propia lengua y cultura, el derecho a su propio territorio, más allá de un simple 
pedazo de tierra para cultivar, y -como colofón- la reformulación de lo que es el Estado, incorporando el reconocimiento de su condición pluriétnica.

En síntesis, todos ellos piensan que sólo llegarán realmente a ser ciudadanos de primera cuando para ello no se les exija en los hechos dejar de ser ellos y asimilarse a otros. Sugieren caminos alternativos que tengan mucho más en cuenta sus especificidades, con el enraizamiento de lo nuevo en sus experiencias acumuladas; un biculturalismo radical que injerte y asimile cualquier innovación dentro del tronco vivo de su propia experiencia. Quieren modernizarse como los demás ciudadanos. Pero para ello, sus organizaciones proponen, de forma cada vez más unánime, otra forma de modernidad, que les incorpore sin que se les exija dejar de ser ellos mismos ni menos quedar marginados de los procesos globales. Quieren una modernización a la vez posmoderna. No buscan el camino de la independencia como en Europa Oriental- sino el reconocimiento, por parte de cada estado, de su carácter pluricultural o incluso, para algunos, plurinacional: es decir, un estado-nación constituido por diversas naciones étnicas en armonía.

Esta presión organizada ha empezado a tener cierto eco en varios países. Por ejemplo, cada vez son más los programas de educación intercultural y bilingüe, varios pueblos indígenas han logrado el reconocimiento siquiera parcial de su territorio y, en lo que, va de los años 90, son ya varios los estados que han reformulado los artículos fundacionales de sus constituciones políticas, reconociendo siquiera el carácter "pluriétnico” de sus sociedades.

\section{Referencias}

ALBÓ, X. Y de kataristas a MNRetistas?: la sorprendente y audaz alianza entre aymaras y neoliberales en Bolivia. La Paz: CEDOIN: UNITAS, 1993.

ALBÓ, X. Nación de muchas naciones: nuevas corrientes políticas en Bolivia. In: GONZÁLEZ CASANOVA, P.; ROITMAN, M. (Ed.). El estado multiétnico y la democracia en América Latina. Madrid: Universidad Complutense. En prensa.

ARIAS, I. COB: la hoz frente al martillo. Cuarto Intermedio, n. 21, p. 79-102, 1991. 
CHUKIWANKA, K. Wiphala comunitaria. In: ENCUENTRO de Estudios Bolivianos. Cochabamba: [s.n.], 1993.

CONTRERAS, A. Etapa de una larga marcha. La Paz: Aquí: ERBOL, 1991.

DEMELAS, M.-D. Darwinismo a la criolla: el darwinismo social en Bolivia, 1880-1910. Historia Boliviana, v. 1, n. 2, p. 55-82, 1981.

MORICIO, D. Memorias de un olvido: testimonios de vida Uru-Murato. Editado por Rossana Barragán. La Paz: HISBOL: ASUR, 1992.

PACHECO, D. El indianismo y los indios contemporáneos en Bolivia. La Paz: HISBOL: MUSEF, 1992.

THOA. El indio Santos Marka T’ula, cacique principal de los ayllus de Qallapa y apoderado general de las comunidades originarias de la República. La Paz, 1984.

TICONA, E.; ROJAS, G.; ALBÓ, X. Votos y wiphalas. La Paz: CIPCA: Fundación Milenio, 1995.

VILLCA, J. de la C. No podemos rezar lo que no es nuestro. Por una Ley que unifique a los pueblos originarias de Bolívia y Awiayala. Informe Rural, La Paz: CEDOIN, n. 45, p. 5, 1991.

WANKAR (REYNAGA, Ramiro). Tawantinsuyu: cinco siglos de guerra qheswaymara contra España. La Paz: MINK’A, 1971. 